\title{
A STUDY ON THE STANDARDIZATION PARAMETERS OF MADHUCA LONGIFOLIA
}

\author{
PRAGATI KHARE ${ }^{*}$, KAMAL KISHORE ${ }^{2}$, DINESH KUMAR SHARMA ${ }^{3}$
}

${ }^{1}$ Department of Pharmacy, Shri Ram Murti Smarak College of Engineering and Technology, Bareilly, Uttar Pradesh, India. ${ }^{2}$ Department of Pharmacy, M.J.P. Rohilkhand University, Bareilly, Uttar Pradesh, India. ${ }^{3}$ Department of Pharmacy, Devsthali Vidyapeeth College of Pharmacy, Rudrapur, Uttarakhand, India. Email: pragatikhare10@gmail.com

Received: 10 March 2017, Revised and Accepted: 19 April 2017

\section{ABSTRACT}

Objective: There is an increase demand of herbal remedies due to their effective and safer way of treating various disorders. In today's scenario, the herbal medicines are much efficient for the treatment of various disorders as they have minimal side effects in comparison to the allopathic medicines. Madhuca longifolia, commonly called Mahua/Mahwa, belongs to the family Sapotaceae. It grows up to a height of about $20 \mathrm{~m}$. The objectives of this study are to investigate various pharmacognostic, phytochemical analysis, and pharmacological properties of M. longifolia.

Methods: The powdered drug was used for estimating the loss on drying, ash values, fluorescence studies, chemical tests, and extractive values. Macroscopic and microscopic studies were also performed.

Results: The leaf microscopy revealed the presence of upper and lower epidermis, palisade tissue, and well-developed vascular bundle. The fluorescence characteristics of leaf powder were studied both in visible light and ultraviolet (UV) light (254 nm and $365 \mathrm{~nm}$ ) after treatment with various reagents. Mahua is composed of glycosides, sapogenins, steroids, saponins, flavonoids, and triterpenoids. It was reported that the total ash value was $5.56 \pm 0.2 \% \mathrm{w} / \mathrm{w}$. The acid-insoluble and water-insoluble ash values were $0.62 \pm 0.025 \% \mathrm{w} / \mathrm{w}$ and $0.47 \pm 0.025 \% \mathrm{w} / \mathrm{w}$, respectively. Water soluble, ethanol, methanol, petroleum ether, and chloroform extractive values were $25.9 \pm 0.51 \% \mathrm{w} / \mathrm{w}, 28.1 \pm 1.38 \% \mathrm{w} / \mathrm{w}, 1.73 \pm 0.20 \% \mathrm{w} / \mathrm{w}$, $0.83 \pm 0.20 \% \mathrm{w} / \mathrm{w}$, and $25.5 \pm 2.29 \% \mathrm{w} / \mathrm{w}$, respectively.

Conclusions: The main pharmacological activities of $M$. longifolia are anthelmintic, antiulcer, antitumor, antimicrobial, antidiabetic, anti-inflammatory, antigoitrogenic, and hepatoprotective. The present investigation provides the information on its pharmacognostic, phytochemical analysis, and pharmacological properties.

Keywords: Mahua, Sapogenins, Flavonoids, Sapotaceae, Ash value.

(C) 2017 The Authors. Published by Innovare Academic Sciences Pvt Ltd. This is an open access article under the CC BY license (http://creativecommons. org/licenses/by/4. 0/) DOI: http://dx.doi.org/10.22159/ajpcr.2017.v10i7.18414

\section{INTRODUCTION}

Madhuca longifolia belongs to family Sapotaceae and is also called Mahua [1]. The term Madhuca is derived from "Madhu" (Sanskrit word) which means honey. It is also known as Indian butter tree. Mahua is a deciduous and medium-sized tree found in India, Nepal, and Srilanka [2]. All the parts of Mahua possess many medicinal qualities. Fruits - refrigerant, aphrodisiac, tonic, and antiulcer. Leaf - wound healing, anthelmintic, emollient, and rheumatism. Flower - refrigerant, liquor, increase milk production in woman, diuresis, antihelmenthic, hepatoprotective. Bark - tonsillitis, stomachache, antivenom in snake poisoning. Oil - laxative, hemorrhoids, piles [3]. It is composed of various phytoconstituents which include flavonoids, triterpenoids, glycosides, saponins, and steroids [4]. M. longifolia can produce about 20-200 kg of seeds/year [5]. The tree of Madhuca longifolia is represented in Fig. 1. The leaves and fruits of Madhuca longifolia are represented in Fig. 2. The flowers of Madhuca longifolia is represented in Fig. 3.

Geographical Source: Mahua is mostly found in the Central and North Indian plains and forests and also in some parts of Eastern India such as West Bengal, Bihar, and Jharkhand [5].

Taxonomical classification $[5,6]$

\begin{tabular}{ll}
\hline Kingdom & Plantae \\
\hline Division & Magnoliophyta \\
Class & Magnoliopsida \\
Order & Ericales \\
Family & Sapotaceae \\
Genus & Madhuca \\
Species & Longifolia \\
\hline
\end{tabular}

Synonyms [6]

\begin{tabular}{ll}
\hline Sanskrit & Atavimaduka \\
\hline Hindi & Mohua, Mungli \\
Telugu & Ippa, Madhukamu \\
Tamil & Iluppai, Kattillupi \\
Odia & Mohuka, Mohulo \\
Malayalam & Illuppa, Iruppapu \\
Kannada & Doddippa, Halippa \\
Urdu & Mahuva \\
Marathi & Moha, Mhowra \\
Gujarati & Mahudo \\
Bengali & Mahula, Kochra \\
\hline
\end{tabular}

Medicinal uses

Its flower is widely used for making local liquor and leaves are used in headache and seed oil for cooking food. The leaf and bark are used for the treatment of skin diseases, rheumatism, and stomachache. Wounds can be treated by applying flower paste [7]. Mahua oil is used for the preparation of detergents, soap, fuel oil, and vegetable butter [2].

\section{Macroscopic characters}

The leaves are simple, alternate, and sinuate margin. The apex is acuminate whereas the base is decurrent. Its texture is glabrous [8].

\section{METHODS}

The leaves of M. longifolia were collected from Guttumal and Company, Shivaji Marg, Bareilly, Uttar Pradesh, India, and identified by Prof. A.K. Jaitly, HOD, Department of Plant Science, Mahatma Jyotiba Phule Rohilkhand University, Bareilly, Uttar Pradesh. 
Powdered drug was used for moisture content, ash values, swelling index, and fluorescence studies were carried out by treating $0.5 \mathrm{~g}$ of powdered drug with different reagents and observation in color was made in visible light, UV light of short $(254 \mathrm{~nm})$ and long wavelength (365 nm) under UV chamber. Photomicrography was done by using Olympus C7070 camera [9].

\section{RESULTS AND DISCUSSION}

\section{Microscopical examination of leaf}

Parenchyma cells form the upper epidermis. The spongy and parenchymatous cells form the mesophyll layer. Vascular bundle was present in the center of the midrib. Xylem was surrounded by phloem. Calcium oxalate crystals were observed in cortex. The T.S. of leaf of Madhuca longifolia is represented in Fig. 4.

\section{Powder study of leaf of $M$. longifolia}

The leaf powder was examined under microscope and crystals, epidermal cells were observed.

Pharmacognostic evaluation of the plant: The plant material was used for quantitative determination of physicochemical values. Ash values, loss on drying, and extractive values were estimated.

Phytochemical Screening: The dried leaves were powdered and extracted with petroleum ether, chloroform, ethanol and water in soxhlet apparatus. The percentage yield was analyzed. The phytochemical tests were performed for the estimation of alkaloids, glycosides, flavonoids, and tannins in various plant extracts and resulted in the presence of

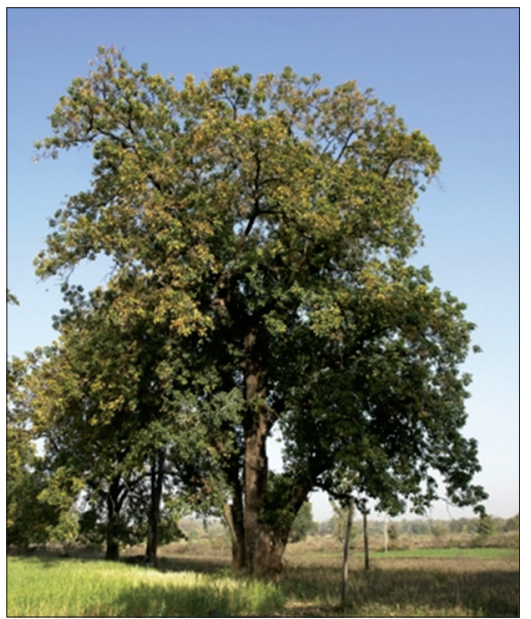

Fig. 1: Tree of Madhuca longifolia

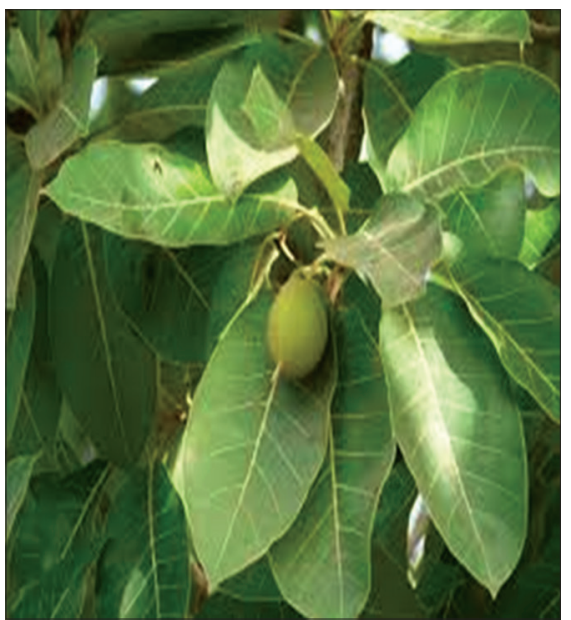

Fig. 2: Leaves and fruit of Madhuca longifolia carbohydrates, gums, proteins, alkaloid, saponins, flavonoids and tannins; results are given in Table 1.

Fluorescent studies of powder drugs: The fluorescence characteristics of leaf powder were studied both in visible light and UV light (254 and $365 \mathrm{~nm}$ ) after treatment with various reagents and is represented in Table $2[10-12]$

The physiochemical parameters of leaf of $M$. longifolia are tabulated in Table 3. The loss on drying at $105^{\circ} \mathrm{C}$ in leaf was found to be $8.5 \pm 0.5 \%$. Total ash value of leaf represents minerals and earthy materials attached in the plant material. It was reported that the total ash value was $5.56 \pm 0.2 \%$. The acid insoluble ash value was $0.62 \pm 0.025 \%$. The water-soluble ash value represents the presence of acids, sugar, and inorganic compounds and was found to be $0.74 \pm 0.025 \%$. The results are given in Table 4

The extractive values of $M$. longifolia in water, ethanol, chloroform, petroleum ether, and methanol were found to be $25.9 \pm 0.51 \% \mathrm{w} / \mathrm{w}$, $28.1 \pm 1.38 \% \quad \mathrm{w} / \mathrm{w}, \quad 1.73 \pm 0.20 \% \quad \mathrm{w} / \mathrm{w}, \quad 0.83 \pm 0.20 \% \quad \mathrm{w} / \mathrm{w}, \quad$ and $25.5 \pm 2.29 \% \mathrm{w} / \mathrm{w}$, respectively.

\section{CONCLUSIONS}

Preliminary phytochemical and physicochemical investigations of M. longifolia were performed in this study. These parameters are necessary for the identification of drugs and investigation of the bioactive constituents in medicinal herbs [13]. The presence of various chemical constituents in M. longifolia may be a potential cause of treatment of various disorders. The quality of the plant

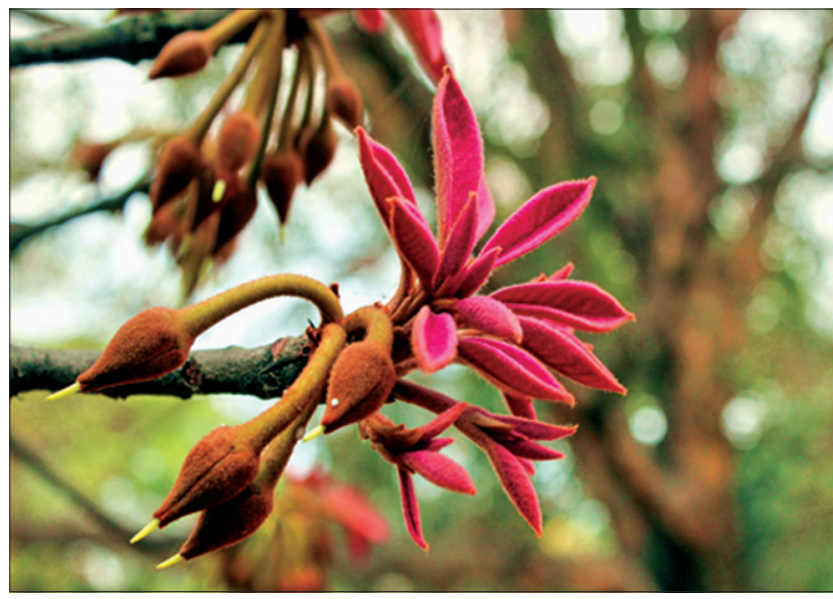

Fig. 3: Flowers of Madhuca longifolia

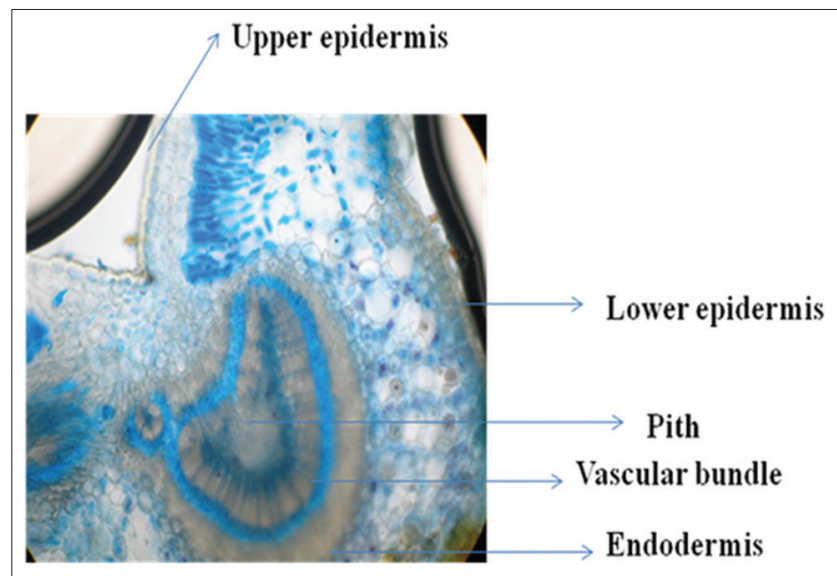

Fig. 4: T.S. of leaf of Madhuca longifolia 
Table 1: Chemical tests

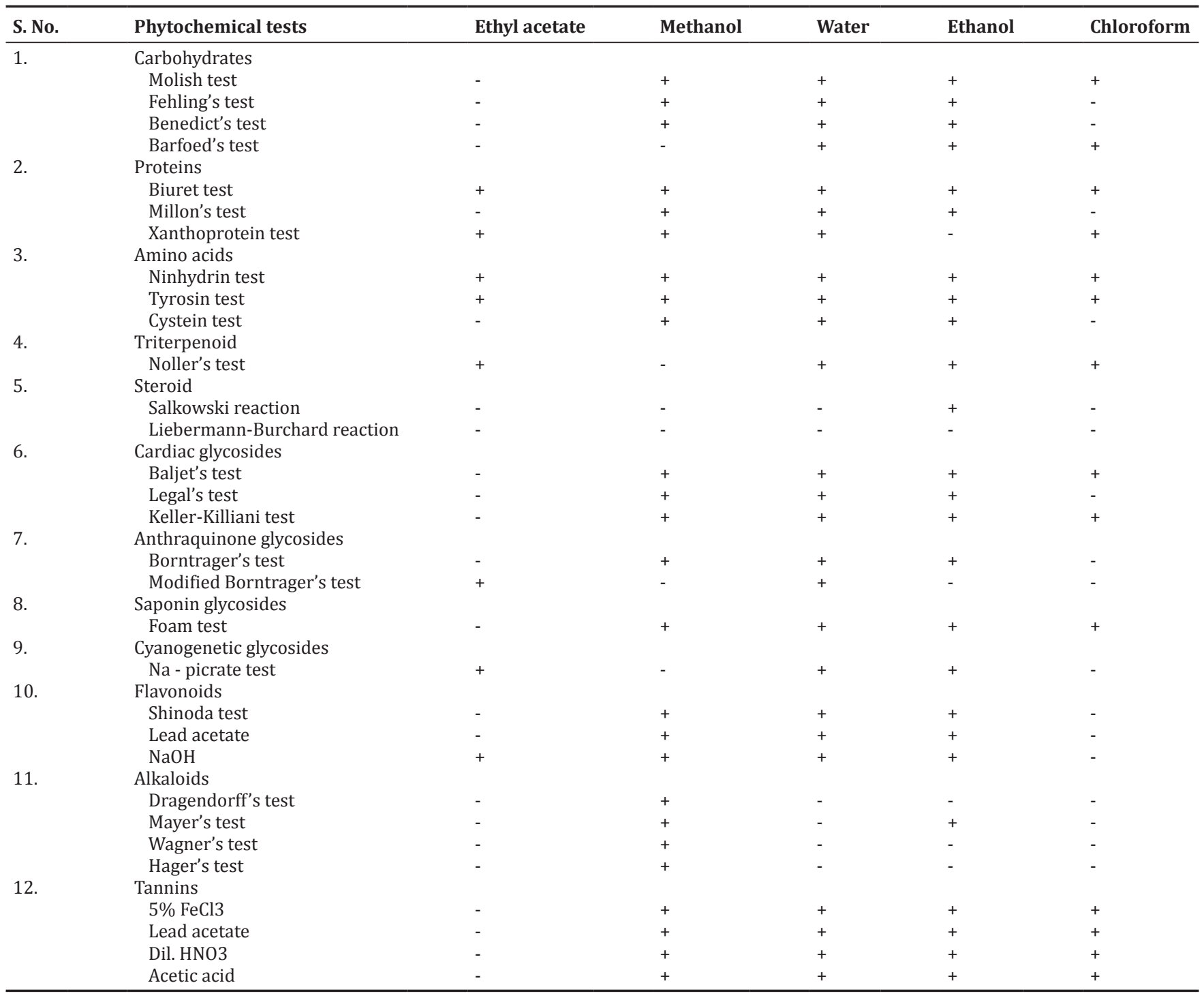

Table 2: Fluorescence activity of Madhuca longifolia leaves

\begin{tabular}{|c|c|c|c|c|}
\hline \multirow[t]{2}{*}{ S. No. } & \multirow[t]{2}{*}{ Material/treatment } & \multicolumn{3}{|c|}{ Observation under UV cabinet } \\
\hline & & Visible light & Short UV 254 nm & Long UV 365 nm \\
\hline 1. & Drug powder as such & Muddy green & Green & Light brown \\
\hline 2. & Powder treated with concentrated $\mathrm{HCl}$ & Light brown & Black & Black \\
\hline 3. & Powder treated with 1 molar $\mathrm{NaOH}$ in water & Brown & Black & Brownish black \\
\hline 4. & Powder treated with concentrated ethanol & Golden & Green & Light green \\
\hline 5. & Powder treated with concentrated acetic acid & Golden & Dark green & Light green \\
\hline 7. & Powder treated with concentrated benzene & Golden & Green & Reddish green \\
\hline 8. & Powder treated with methanol & Green & Dark green & Yellowish green \\
\hline 9. & Powder treated with $1 \mathrm{M} \mathrm{H}_{2} \mathrm{SO}_{4}$ & Light green & Dark green & Blackish green \\
\hline 10. & Powder treated with concentrated $\mathrm{HNO}_{3}$ & Red & Reddish black & Black \\
\hline 11. & Powder treated with petroleum ether & Light green & Black & Dark green \\
\hline 12. & Powder treated with distilled water & Green & Greenish brown & Brown \\
\hline
\end{tabular}

UV: Ultraviolet

can be estimated by determining the physical parameters. These investigations are of great importance for carrying out the revalidation and estimation of its other pharmacological activities. It was concluded from the phytochemical study that the ethanolic extract contains flavonoids, glycosides, carbohydrates, tannins which are responsible for various pharmacological activities such as anti- inflammatory, chemoprotective activity, antioxidant, antidiabetic, antianxiety, and antidepressant.

\section{ACKNOWLEDGMENTS}

We are thankful to the Management of Department of Pharmacy, Shri Ram Murti Smarak, C.E.T., Bareilly, Uttar Pradesh, India, for providing 
Table 3: Physiochemical parameters

\begin{tabular}{|c|c|c|c|c|c|}
\hline S. No. & Parameters & Values $(\% \mathrm{w} / \mathrm{w})$ & Values $(\% \mathrm{w} / \mathrm{w})$ & Values $(\% \mathrm{w} / \mathrm{w})$ & Mean \pm SD $(\% \mathrm{w} / \mathrm{w})$ \\
\hline 1. & Total ash value & 5.50 & 5.4 & 5.8 & $5.56 \pm 0.2$ \\
\hline 2. & Water-insoluble ash value & 0.45 & 0.47 & 0.5 & $0.47 \pm 0.025$ \\
\hline 3. & Water-soluble ash value & 0.75 & 0.77 & 0.72 & $0.74 \pm 0.025$ \\
\hline 4. & Acid-insoluble ash value & 0.60 & 0.65 & 0.62 & $0.62 \pm 0.025$ \\
\hline 5. & Loss on drying & 9.0 & 8 & 8.5 & $8.5 \pm 0.5$ \\
\hline
\end{tabular}

SD: Standard deviation

Table 4: Extractive values of Madhuca longifolia L.

\begin{tabular}{|c|c|c|c|c|c|}
\hline S. No. & Solvent & Extractive value $(\% \mathrm{w} / \mathrm{w})$ & Extractive value $(\% \mathrm{w} / \mathrm{w})$ & Extractive value $(\% \mathrm{w} / \mathrm{w})$ & Mean \pm SD $(\% \mathrm{w} / \mathrm{w})$ \\
\hline 1. & Water & 25.5 & 26.5 & 25.8 & $25.9 \pm 0.51$ \\
\hline 2. & Ethanol & 28.8 & 29 & 26.5 & $28.1 \pm 1.38$ \\
\hline 3. & Chloroform & 1.8 & 1.5 & 1.9 & $1.73 \pm 0.20$ \\
\hline 4. & Petroleum-ether & 0.9 & 1 & 0.6 & $0.83 \pm 0.20$ \\
\hline 5. & Methanol & 26.0 & 23 & 27.5 & $25.5 \pm 2.29$ \\
\hline
\end{tabular}

chemicals and other infrastructure for doing this research work. The work is dedicated to my guide and coguide.

\section{REFERENCES}

1. Dahake AP, Chakma CS, Chakma RC, Bagherwal P. Antihyperglycemic activity of methanolic extract of Madhuca longifolia bark. Diabetologia Croat 2010;39(1):3-8.

2. Annalakshmi R, Uma R, Chandran GS, Sahayam CS, Charles A. Evaluation of physico-chemical constants and phytochemical analysis of Madhuca longifolia. Int J Nat Prod Res 2012;1(3):64-6.

3. Akhil M, Sarma SK, Poornachandrarao GV, Jyothi CH, Kumar RD, Kumar BR. Evaluation of anthelminthic activity of leaves of Madhuca longifolia. Int J Pharmacol Toxicol 2014;4(2):99-104.

4. Kumar KP, Vidyasagar G, Ramakrishna D, Reddy IM, Gupta VS, Raidu CH. Screening of Madhuca indica for antidiabetic activity in streptozotocin and streptozotocin - Nicotinamide induced diabetic rats. Int J Pharmtech Res 2011;3(2):1073-7.

5. Datta A, Pal A, Bandyopadhyay A. A study on the effect of habitual consumption of Madhuca longifolia drinks on the prevalence of diabetes and dyslipidemia among Santhal tribals. Int J Basic Clin Pharmacol 2016;5(3):1108-11

6. Kumar A. A review on Madhuca longifolia. Res Pharm Health Sci
2016;2(3):187-95.

7. Eswaraiah MC, Elumalai A, Rahman H. Isolation of phytochemical constituents from stem barks of Madhuca longifolia. Int Res J Pharm Appl Sci 2011;1(1):43-60

8. Moteriya P, Padalia H, Rathod T, Desai D, Chanda S. Pharmacognostic standardization of Madhuca longifolia leaf and stem, An important medicinal plant. Int J Pharm Sci Res 2015;6(2):705-11

9. Sunita P, Jha S, Pattanayak SP. Anti-inflammatory and in-vivo antioxidant activities of Cressa cretica Linn. A halophytic plant. Middle East J Sci Res 2011;8(1):129-40.

10. Prasad V, Kadam R, Deoda S, Rakesh S. Pharmacognostic, phytochemical and physiochemical studies of Mimusops elengi Linn stem bark (Sapotaceae). Pharm Lett 2012;4(2):607-13.

11. Arulanandraj N, Gopal V. Phytochemical screening of roots extracts of Marva (Maerua oblongifolia). Int J Univ Pharm Life Sci 2011;1(2):282-93.

12. Katara A, Pradhan CK, Tyagi AK, Singh P. Phytochemical investigation and antimicrobial activity of Leucas cephalotes Roth. Spreng whole herb. Pharm Chem 2010;2(4):284-96.

13. Yadav M, Chatterji S, Gupta SK, Watal G. Preliminary phytochemical screening of six medicinal plants used in traditional medicine. Int $\mathrm{J}$ Pharm Pharm Sci 2014;6(5):539-42. 